\title{
THE LINKS BETWEEN WOMEN TRAFFICKING AND ORGANIZED CRIME IN POST- YUGOSLAV SOCIETIES
}

\author{
Tanja Miloshevska, PhD \\ Ss.Cyril and Methodius University, Faculty of Philosophy, \\ Institute of security, defense and peace, the Republic of Macedonia \\ Desirée Pangerc, PhD \\ Padova-Italy, \\ Royal Anthropological Institute of Great Britain and Ireland (UK)
}

\begin{abstract}
Human trafficking is the only part of transnational organized crime in which women are notably represented - as victims, perpetrators, and as activists seeking to combat this crime. Woman trafficking is a large and rapidly growing component of transnational organized crime. The paper focuses on the main aspects and trends in women trafficking and expands upon the knowledge of activities carried out by human traffickers with a focus on links to organized crime. Particularly, the paper implies to answer the question, "What link exists between women trafficking and organized crime?" This paper aims to research women trafficking in the post-Yugoslav societies and to gain better understanding of this phenomenon that represent one of the security problems for this region. The violent Yugoslav disintegration and economic decline altered traditional social relations in ways that led to more exploitative trafficking exchanges of women and young girls and the proliferation of new networks of suppliers, distributors, and clients. More research in this field would allow a comprehensive understanding of the underground alliances and the different roles organised criminal groups can play in this context.
\end{abstract}

Key words: human trafficking, women trafficking, organized crime, violence, postYugoslav societies.

\section{Introduction}

Unbridled ethnic conflict on a scale not witnessed in Europe since 1945, several episodes of external intervention (often involving the overwhelming use of force), and the 
unabated use of violence by criminal elements provided waves of challenges to civil society in the Balkan region. As the more explicit challenges to law and order-genocidal activities and overt civil war-were quelled through external intervention, transnational crime surged. Transnational crime networks have long historical records in the Balkans, and include cigarette, heroin, and arms trafficking that predate the collapse of Yugoslavia. Nonetheless, the Yugoslav wars and their aftermath intensified the scale of transnational crime and the levels at which criminal networks preyed on the population. (Friman \& Reich 2007).

Trafficking of women for sexual services is best understood in the context of cultural practices and economic incentives. Long (2006) posits trafficking as an exchange transaction involving an array of different parties and women as objects/providers of services being exchanged. The motivations of such actors, conditions and organizational patterns that facilitate the trafficking exchange are worth in-depth analysis. The forms of exchange transactions differ a lot. Long also focuses on "the gift, the service and the commodities exchange" and, drawing on examples from Post-Yugoslav societies, traces the ways in which these dimensions have changed over time. For example, gift transactions involving women have a long history in the Balkans.

However, the violent Yugoslav fragmentation and economic downturns altered traditional social relations in ways that led to more exploitative trafficking exchanges of women and young girls and proliferation of new networks of suppliers, distributors, and clients.

\section{Root causes of Women Trafficking in Post-Yugoslav Societies}

\section{The Transition to a Free-Market Economy}

The process of economic transition has led to a decrease in the quality of life and the accelerated spread of poverty to a large portion of the population in the countries of South Eastern Europe and the former Soviet Union. Women have been particularly vulnerable to trafficking networks because the post socialist transition has displaced many of them, and because the "feminization of poverty" has been particularly acute in the former socialist countries (Moghadam, 2005). The transition process in the countries of former Yugoslavia has also led-as a secondary effect-to weakening of state institutions. Simultaneously, the institutions have become even weaker due to the widespread corruption. It is estimated that the degree of the increase in criminal activity in most 
countries in the region is inversely proportional to the successes that the respective states have achieved in implementing market economy and democratic reforms.

Expansion of neoliberal capitalism, deepening gap between poor and rich countries, and the dependent development of post-communist countries do not give ground for expectation of any stable welfare state in near future (Sklair, 1991: 233). The costs of economic change are very high, especially in poorer and war-torn countries. The new forms of exploitation and slavery are hidden in the obscure spaces of the market economy: migrants and criminal organizations find a sort of common agreement, even though this relationship is clearly asymmetric in favor of the exploiters, who have capital, information, logistic support, knowledge of the territory and well established social networks (Pangerc 2012).

Both globalization and the development of organized crime are important factors which facilitate sex trafficking (Williams, 1999: 202). The confluence of two forces has enabled the development of the sex industry, which is "based on and perpetuated by prevailing unequal socially and culturally defined gender and power relations." Immigration laws and policies in destination countries, including policies on migrant labor, migration, and prostitution, and corrupt officials in sending, transit, and destination countries, further contribute to the development of sex trafficking merely by making organized crime possible (Konig, 1997: 17).

\section{The Opening of the Borders}

It is well known that much of the "new" trade in human beings has emerged from the former socialist bloc since the opening of the borders at the beginning of the 1990s, after the end of the Cold War (Shelley, 2003). Moreover, opening of the borders has led not only to the increase of cooperation at all levels between countries in countering illegal immigration, but also to rise of organized criminal activity, including human trafficking. The Balkans, with the large presence of international administration, organizations, police, and military forces, the attendant confusion in jurisdiction, corruption, and inefficient and biased law enforcement system, and its short distance from the post-communist countries with large supplies of desperate women, is ideal destination for traffickers wishing to avoid risks and unnecessary expenses. Moreover, women from other East European countries usually do not need visas to get to the former Yugoslavia, which make traffickers' tasks even easier. 
When recruiting women, organized crime relies largely on myths about Western countries which exist among women in post-communist countries.

\section{The Existence of a Developed "Black Market"}

As it is the case with all forms of organized crime, the existence of a developed "black market"-even since the communist period-has played a major role in the establishment and development of illegal networks and routes of traffic. All the centralized economies of Eastern Europe harbored developed black markets, due to the incapacity of the official economies to meet consumers' basic needs. Against this backdrop, after 1990 different criminal groupings began to appear, taking advantage mainly of the weakness of the state and the corruption of state structures.

\section{The Wars in the Former Yugoslavia}

The collapse of Yugoslavia and the wars that emerged led to the increase of organized criminal activities in South Eastern Europe. The need to finance war efforts of the various groups involved in the conflicts led to the appearance of a so called "war economy," which generated its funds from illegal activities (Caldor, 1999). The networks and markets established during the war were maintained even after the war ended, as they had proved themselves to be very efficient. Sometimes even the peacekeeping forces were involved in such activities (mainly human trafficking and prostitution). Moreover, in addition to their occasional active involvement, the peacekeeping forces formed an important consumers' market for the products of these criminal groups (Report, 2003). The ethnic, religious, social, and national differences that are supposedly so deeply rooted in the Balkans disappear when it comes to the money generated by these illegal activities.

\section{4a) Sex Trafficking During and After Ethnic Conflicts}

Ethnic conflicts in the former Yugoslavia have contributed significantly to the vulnerability of women to sex trafficking. Although only sporadically mentioned in works on wartime sexual violence, sexual slavery and sex trafficking is strongly connected to war rapes and forced prostitution. Post-war militarization and the large presence of 
international organizations further contributed to the growth of sex trafficking in the Balkans.

Because of its better economic situation at the beginning of 1990s, Serbia was one of the main destination countries within Eastern Europe at least for certain period of time. Later on Serbia became mainly a transit country, both to neighboring territories where the raging war brought a large military presence, and to Western Europe. Women from the Ukraine, Russia, and Romania make up the majority of women trafficked through Serbia. They are most often used as prostitutes in Serbia for some time and then sold further, mainly through Montenegro to Italy. A similar situation exists in Macedonia. Although the economic situation in Macedonia was difficult throughout the transition, its geographic position, large presence of NATO forces, and strong Albanian mafia contributed to it becoming one of the main transit countries for many trafficked women (Bacanovic, 2001). Women from Bulgaria, the Ukraine, Mongolia, Moldova, Romania, and Albania prevail among those trafficked to or through Macedonia. From there, women are trafficked to the Middle East and Western Europe, mainly via Greece. Serbia and Macedonia are often transit countries for the trafficking of women from other East European countries to Kosovo, as well. According to official data, more than a half of women whom IOM assisted entered Kosovo from Serbia, and about a third of them entered from Macedonia. Also, women sometimes enter Kosovo from Albania. Women are usually sold three to six times during their journey to Kosovo (IOM 2000-2001).

Thus, the geographical position of the Yugoslavia predestined it to a role of crossroads for different illegal channels. This makes trafficking in women (as well as other forms of transnational crime) in the Balkans a particular case in comparison to both Western countries and other parts of Eastern Europe. As a consequence, factors which contribute to trafficking in women from, through and to the Balkans are connected with the ethnic conflicts in the former Yugoslavia and with the transition from communism in Eastern Europe, as well as with the broader processes of militarization and globalization of the region.

\section{Violent Entrepreneur Model - Balkan Crime Groups}

The Violent Entrepreneur Model pertains almost exclusively to the trafficking of women. These crime groups do not traffic laborers, although they traffic drugs and arms along the same routes and sometimes move all of these commodities simultaneously. Their human victims are large numbers of women from Balkan states, as well as women from the 
former Soviet Union and Eastern Europe sold to Balkan crime groups. These criminal groups initially made their profits by offering the women to peacekeepers stationed in Kosovo. They also developed extensive international networks, running an integrated business by controlling the women from the time of "acquisition" in the Balkans through their exploitation in the brothels of Western Europe.

This is an opportunistic model in both the source and recipient countries. The civil conflict and subsequent instability in the Balkans in the 1990s resulted in large numbers of vulnerable women. Female victims were often those whose families had died or women seized as part of blood revenge by one family against another. The women had already been traumatized by the violence of war or that of internecine feuds among families and clans. Balkan traffickers operate within family groups. Therefore, although men control the organizations, there are cases in which female family controls operations in a particular country or region members or by outsiders (Shelley, 2010).

This model results in very significant violations of human rights and terrible violence against trafficked women. The model's reliance on violence in all stages of its operations makes it the most serious violator of human rights. Threats to family members at home are combined with terrible physical abuse of the women.

Organized criminal groups increasingly deal with trafficking for forced prostitution because of the low risk of apprehension and the relatively light penalties criminals receive if caught. There are two other factors influencing the rise of criminal activities in this area:

The first is that it is the most lucrative kind of business among human trafficking and smuggling activities. According to Interpol an exploiter can earn over 100.000 Euros a year on each woman exploited;

The second is that trafficking for sexual exploitation often develops and builds on the local underworld's rings, which traditionally control the exploitation of prostitution. On the expertise and cultural profile, organized crime groups have not difficulties in dealing with them. There are different ways for traffickers to enter into underground system of prostitution.

Some traffickers rely on pre-existent networks of sexual exploitation to supply trafficked women and girls; others run the business independently, creating their own structures for the exploitation of women and girls.

The worldwide expansion of trafficking activities is not always sponsored by complex criminal organizations: free-lance traffickers and small enterprises are also very active in the field. Considering their size, the degree of integration in the underworld 
system of prostitution, as well as in legal society, some distinctions can be made among the criminal groups that can be roughly divided into three main categories:

1. small and loosely connected criminal groups,

2. middle-size criminal groups, and

3. Complex trans-national criminal organizations (Monzini, 2001).

In the small and loosely connected criminal groups, usually recruiters also act as transporters and exploiters, and they are friends or acquaintances of the future victims. Once abroad they introduce them to the established criminal networks (preferably of the same nationality) which are a part of the lowest circles of illegal prostitution.

Middle-size criminal groups are different from small organizations in that they specifically provide trafficked women and girls to supply sex markets of foreign countries. Some of these groups focus their activities uniquely on the recruitment and transport of victims. They make profits "selling" their victims to intermediaries and procurers in the industry's main transit points, in particular the capital cities and/or border areas. More sophisticated middle-size groups organize the so-called "mobile prostitution" (Nurmi, 1999). It consists in moving or rotating trafficked women from one place to another, both internally within a country, and across national borders, mainly to western European countries.

Prostitution is prohibited by law in most Balkan countries and it becomes not only a serious social problem, but also an important source of income for organized crime (Sarang \& Hoover, 2005:19).

Finally, more complex transnational criminal organizations are those able to control and co-ordinate every phase of the trafficking procedure, from the recruitment of women and girls in their origin countries to their exploitation abroad. These networks are highly specialized. Several professional figures, some of which are well integrated in legal society, partake in the business.

\section{Recent Trends on Women Ttrafficking in Post-Yugoslav Societies}

In the Post-Yugoslav countries, the increase in demand and supply for trafficking has lead to the growth of the trafficking in women and girls for sexual exploitation.

However, this paper reveals an even greater complexity in trafficking patterns in the region.

These patterns vary extensively by the country of origin and ethnicity of the women being trafficked; by economic conditions within different areas of individual countries and 
relative to other countries in and outside of the region; and by shifting patterns of local and foreign demand.

Slovenia is a destination and, to a lesser extent, a source and transit country for women and children subjected to sex trafficking (Trafficking in Person Report (TiPR), 2015). Women from Slovenia, Moldova, Serbia, Croatia, Ukraine, Romania, Slovakia, the Czech Republic, and the Dominican Republic are subjected to forced prostitution within the country and transit through Slovenia to Western Europe, primarily to Italy and Germany, where they face the same form of exploitation. From the prosecution point of view, the Government of Slovenia demonstrated improved anti-trafficking law enforcement efforts in 2012, as trafficking investigations and prosecutions increased and its judiciary utilized the trafficking statute to convict trafficking offenders. Slovenia prohibits all forms of trafficking in persons through Article 113 of its criminal code, which prescribes penalties ranging from one to 15 years' imprisonment for offenses. (Trafficking in Person Report (TiPR), 2015).

Women and girls from Croatia, some of whom respond to false job offers online, fall victim to sex trafficking within the country and throughout Europe. Women and girls from the Balkans and Eastern Europe are subjected to sex trafficking in Croatia. Trafficking convictions increased but law enforcement efforts remained inadequate relative to the size of the problem, with light sentencing for perpetrators. The government identified more victims, but experts believed the true extent of trafficking in Croatia remained higher than the number of victims identified by the government. Croatia prohibits all forms of trafficking through Articles 105 and 106, which prescribe penalties of one to 15 years' imprisonment. (Trafficking in Person Report 2015).

According the US State Department report, Bosnia and Herzegovina was the only country that fulfills the minimum standards for combating trafficking (Tier 1 in 2010, 2011), and which in recent years has managed to make clear progress in its efforts to implement legislation on trafficking. But in 2012-2015 the state has dropped into Tier 2 (TiPR, 2015). In the view of the general characteristics stated for the Balkans, Bosnia and Herzegovina is also a country of origin, transit and destination for victims of trafficking, especially women and young girls recruited for forced prostitution, as well as other countries in Western Europe. Ffor example, local women were trafficked out of the country while women from elsewhere in the region were trafficked into the country for prostitution networks that focused on the growing international community as clientele. Women and girls from the European countries are subjected to sex trafficking within the country. The Bosnian victims are subjected to sex trafficking and forced labor in construction and other sectors in 
countries across Europe including Azerbaijan, Montenegro, Croatia, Serbia, and Austria. Police corruption creates an environment enabling some trafficking crimes. (TiPR, 2015). The government demonstrated mixed progress on anti-trafficking law enforcement efforts. Bosnia prohibits sex trafficking and forced labor through Article 186 of the Criminal code, which prescribes penalties of three to 10 years' imprisonment.

Serbia is a source, transit, and destination country for women subjected to sex trafficking and forced labor, including domestic servitude and forced begging. Local women are subjected to sex trafficking by Serbian criminal groups in Russia, neighboring countries, and throughout Europe, particularly Italy, Germany, and Switzerland (TiPR, 2015). Foreign victims of trafficking in Serbia are from the neighboring countries including Montenegro, Bosnia and Herzegovina, Bulgaria, Romania, and Moldova. Bribery reportedly influences some trafficking cases. Foreign victims were transported to Serbia from Eastern Europe and Central Asia via Kosovo and Macedonia. Serbia serves as a transit country for victims who are transferred from Bosnia, Croatia and Slovenia, for Italy and other countries in Western Europe. Minors, mostly Roma, are traded for sex, forced marriages and begging. The majority of identified victims of trafficking in 2008 were of Serbian origin - out of which more than half were children. Human trafficking is punishable under criminal legislation with imprisonment of three to fifteen years. (Before the amendments from August 2009 the sentence for the crime human trafficking was imprisonment from two to ten years).

Montenegro is a country of origin, transit and destination for victims of trafficking, exploited mainly for prostitution and forced work. According to the US State Department, she is also a Tier 2 country from 2010-2015 that does not comply with the minimum standards for the elimination of human trafficking. Montenegro is commended though for investing considerable effort and for the first time publicly acknowledging that the problem of human trafficking exists in its territory. However, the problem of lack of state mechanisms for identifying the victims still exists. The reports from the US State Department from 2009-2012 (Human Rights report, 2012), recommended that Montenegro take aggressive measures to conduct vigorous investigations to prevent crimes of human trafficking, especially for sexual exploitation and forced service operations, and to work on identifying victims and providing assistance for their protection, and particularly highlighted the need to improve special protection to child victims of trafficking. Victims are primarily women and girls from Montenegro, Serbia, Macedonia, Bosnia, Kosovo, and to a lesser extent, other countries in Eastern Europe (TiPR, 2015). It is 
believed that criminal networks operate as well in the field of tourism and in trade in young women and girls for sexual exploitation. Internationally organized criminal groups occasionally subject Montenegrin women and girls to sex trafficking in the other Balkan countries. Montenegro prohibits sex and labor trafficking through Article 444 of its criminal code, which prescribes penalties of up to 10 years' imprisonment.

The lack of visa requirements for most travelers makes it Kosovo a vulnerable transit country. Most sex trafficking victims in Kosovo are female citizens, though women from Moldova, Slovakia, Albania, Serbia, and Poland also face forced prostitution in Kosovo. Kosovo's new criminal code and criminal procedure code took effect in January 2013 (TiPR, 2013). Most sex trafficking victims are girls, though criminal groups in Kosovo also force women from Albania, Serbia, Romania, and other European countries into prostitution. Women and girls are subjected to sex trafficking in private homes and apartments, nightclubs, and massage parlors. Traffickers promise employment as dancers and singers in restaurants, and instead force victims into sex trafficking. Traffickers subject Kosovo citizens to forced prostitution and forced labor throughout Europe. Article 171 of Kosovo's Criminal code prohibits all forms of trafficking and prescribes punishments of five to 12 years' imprisonment and a fine of up to 500,000 euro $(\$ 608,000)$ (TiPR, 2015).

The traffickers also reveal considerable diversity, ranging from family members of victims, to local and foreign organized criminal networks, to corrupt government officials and members of international stabilization and police forces charged with helping to rebuild order in the region. This diversity, and especially the participation of the latter groups in human trafficking, represents a profound challenge to the establishment of the rule of law.

\section{Dimensions of Women Trafficking in Macedonia}

Historically located at the major crossroads of the Balkans, Macedonia has been fertile ground for human trafficking since long ago. Now Macedonia joins Croatia and Slovenia as the only countries in the region with Tier One status, according to the cited US State Department report on the achievements of countries in this area in 2013. According to the report, countries are put in three categories: Tier One, Two and Three, with Tier One being for countries that have fulfilled all conditions. Macedonia received Tier 0 ne status for the first time in 2008, and has maintained it ever since except in 2010-Tier 2, by breaking up human trafficking chains and prosecuting perpetrators - particularly along the porous western and north-western borders - as well as by providing shelters and services for the victims. 
Today Macedonia is one of the leading Balkan countries in terms of the legal structure and the measures taken to combat human trafficking in general. Significant improvements have been mad to the criminal legislation, covering this crime. These raised the battle for combating the crime to a higher level and contributed to the country begin qualified as a country that fulfills the minimum standards to combat trafficking, which is a step ahead of other countries in the region.

However, Macedonia remains a source, transit and destination country for children and women victims of sexual exploitation. Most of the victims come from Roma population. Foreign victims originate from Albania, Bulgaria, Serbia, Bosnia, Ukraine, and Kosovo. The Macedonian citizens are subjected to trafficking in Greece, Belgium, and other countries in Europe (TiPR, 2013). Macedonia is one of the few countries in the region, which was able to put into practice improved legislation. Amendments to the criminal Code (Gazette of RM, 2002; Gazette of RM, 2004; Gazette of RM, 2008; Gazette of RM, 2009) have helped to combat trafficking in minors and human beings and stiffened penalties. What was once a weak tool for combating this type of crime is now transformed into a detailed, comprehensive base which can be used to seriously combat human trafficking (Ivanova, 2013).

Analyzing the laws in the Balkan states against human trafficking one may notice especially Articles 418(a) and (d) of the Macedonian Criminal code, which prescribe a minimum penalty of four years' imprisonment for trafficking of adults and eight years' imprisonment for trafficking of children. The separate article in combating trafficking with minors means better legislative solution than in the other Balkan countries. However, all countries in the region have made changes in the overall attitude in the fight against trafficking in persons in order to comply with international regulations, especially the Palermo Protocol of 2000.

The biggest problem however remains trafficking of girls, especially minors, for sexual abuse. Macedonia is, like its neighbors, mostly a transit country, due to its geographic location. But is also a country of origin and destination. So, young girls are transported through or to the country for abuse. Foreign victims subjected to sex trafficking in Macedonia typically originate from Albania, Bosnia and Herzegovina, Kosovo, Romania, Serbia, and Ukraine. The Macedonian citizens are subjected to sex trafficking and forced labor in construction and agricultural sectors in Southern, Central, and Western Europe (TiPR, 2015). 
The breakdown of law and security regimes in war-torn countries or countries in transition creates a breeding ground for trafficking in human beings. Wide range of criminal organizations has been reported in South Eastern Europe, ranging from cell-like structures to the loose networks involved in variety of transnational criminal activity, including human trafficking. Their cohesion is based on former political and economic liaisons, on ethnicity or kinship, and-with the use of corruption, violence, and exploitation of public services-on the steady links that have been built up between legal and illegal enterprises (Chatterjee, 2005).

The main routes towards Western Europe are the following: firstly, via Bosnia and Herzegovina, Croatia and partially Slovenia to Italy or Austria; secondly, from Moldova, Romania, Serbia and Montenegro to Albania, and across the Adriatic Sea into Italy; thirdly, from Romania, Bulgaria, Albania and Macedonia to Greece. The changing geographical nature of trafficking facilitates the speed and flexibility of its organizers' ability to shift the 'trade' to areas of stronger demand in a short time, building up new transit routes from countries of supply, cunningly using the existing infrastructure of local travel and job agencies, and discovering a whole network of new middlemen and dubious entrepreneurs interested in the influx of illicit labor. Local criminal groups controlled by transnational networks rushed to build up local chains of brothels targeting peacekeepers as clients, as happened in Kosovo, where a chain of brothels had already been opened before the arrival of the first peacekeepers to the region (Piccarelli, 2002).

At the regional level, the traffic in human beings "represents a very serious and growing threat, not only for the countries in the region, but also for the rest of Europe," since "the Balkans has become the gateway to Europe for organized criminals." (Blunket, 2002). It is an issue of critical importance not only because it infringes upon and challenges the protection of human rights, but also because it has the potential to undermine the process of democratization, discredit the rule of law, weaken efforts to reform and build institutions, promote corruption, and even to threaten the stabilization process in the region.

\section{Reflections}

Human trafficking is a growing transnational criminal phenomenon and formidable challenge to national and international security. Although it is not a new phenomenon, it has spread to new regions of the world and become a large part of the illicit global 
economy. This paper focuses upon the trafficking of women for sexual exploitation, as this appears to be the most serious and growing form of trafficking in the region of postYugoslav countries. A remarkable decline in the standard of living and an increase in insecurity, largely flexibility, instability, and war victimization have led to continued sex trafficking over the last decade. The results from war-torn or unstable regions show that, by dejection legal labor markets and impeding governments in economic and political transition or post-conflict reconstruction, women trafficking contribute to the maintenance of an unstable and fragile political environment.

Simply by critically concentrate and eliminating structural violence we can address the crucial problem in sex trafficking in the post-Yugoslav and other post-conflict societies.

\section{Bibliography}

1. Bacanovic, 0. (2001). "Women Victims of Human Trafficking", Yearbook of the School of Security in Skopje, 104-116.

2. Blunkett, D. (2002). Defeating Organized Crime in South Eastern Europe, Lancaster House Ministerial Conference.

3. Caldor, M. (1999). New and Old Wars: Organized Violence in a Clobal Era, Stanford University Press, California.

4. Chatterjee, J. (2005). The Changing Structure of Organized Crime Groups. Ottawa: Royal Canadian Mounted Police, 12, doi: http://dsp-psd.pwgsc.gc.ca/Collection/PS64-9-2005E.pdf.

5. International Organization for Migration. (2000-2001). Return and Reintegration Project, situation report, February 2000-May 2001, Pristina, 6-7.

6. Ivanova, E. (2013). "Comparative View of the Problem with Human Trafficking In the Balkan Countries". Balkan Social Science Review (BSSR), 1 (1).

7. Friman, R., \& Reich, S. (Eds). (2007), Human trafficking in the Balkans, University of Pittsburgh Press.

8. Human Rights Report: Serbia, (2012). U.S Department of State, doi: http://podgorica.usembassy.gov/trafficking_in_persons_report2012.html

9. Konig, I. (ed.). (1997). Trafficking in Women, Vienna: Federal Chancellery.

10. Long, D. Lynellyn. (2006). Trafficking Exchanges and Economic Responses: Reflections from Bosnia-Herzegovina and Serbia, Johns Hopkins University. 
11. Moghadam, V. M. (2005). "The Feminization of Poverty and Women's Human Rights", SHS Papers in Women's Studies/ Gender Research No. 2, doi: http://portal.unesco.org/shs/en/file_download.php/1ec293d182a88561926ecaac40 3c5642Feminization+of+poverty.pdf.

12. Monzini, P. (2001). "Trafficking in Women and Girls and the Involvement of Organised Crime, with reference to the situation in Central and Eastern Europe", Annual Conference of the European Society of Criminology.

13. Nurmi, R. (1999). "Mobile Russian Prostitution in Finland". 32nd Triennial Conference of thelnternational Abolitionist Federation, Breakdown of Borders, Copenhagen, Denmark.

14. Official Gazette of Republic of Republic of Macedonia. (2002). 04/02.

15. Official Gazette of Republic of Republic of Macedonia. (2004). 19/04.

16. Official Gazette of Republic of Republic of Macedonia. (2008). 7/08.

17. Official Gazette of Republic of Republic of Macedonia. (2009). 114/09.

18. Official web site of U.S Department of State, doi: http://www.state.gov/j/tip/rls/tiprpt/2012/192363.htm

19. Pangerc, Desirée (2012), // traffico degli invisibili. Migrazioni illegali lungo le rotte balcaniche. Roma: Bonanno Editore.

20. Piccarelli, J. (2002). Trafficking Slavery and Peacekeeping: The Need for Comprehensive Training Program, A Conference Report, Turin: UNICRI and TraCCC.

21. Romanian Centre for Journalism of Investigation. (2003). Trade with Poverty, Human Beings Trafficking. Report on the Human Beings Trafficking in the Balkans, doi: www.proiect.ns/archives/000032.html.

22. Sarang, A. \& Hoover J. (eds.) (2005). Sex work, HIV/ AIDS, and Human rights in Central and Eastern Europe and Central Asia, the Central and Eastern Europe Harm Reduction Network.

23. Shelley, L. (2003). Human Trafficking: Transnational Crime and Links with Terrorism, Statement to the House Committee on International Relations Subcommittee on International Terrorism, Non-proliferation and Human Rights, doi: http://usinfo.state.gov/eap/Archive_Index/Human_Trafficking_Transnational_ Crime_and_Links_with_Terrorism.html.

24. Shelley, L. (2010). Human Trafficking: A Global Perspective, Cambridge University Press, UK.

25. Sklair, L. (1991). Sociology of the Global System, Hertfordshire: Simon \& Schuster. 


\section{Security}

26. The State Department 2013 Trafficking in Persons Report, doi: http://www.state.gov/j/tip/rls/tiprpt/2013/

27. The State Department 2015 Trafficking in Persons Report, doi: http://www.state.gov/j/tip/rls/tiprpt/

28. Williams, P. (1999). "Trafficking in Women and Children: A Market Perspective", Transnational Organized Crime, Special Issue "Illegal Immigration and Commercial Sex - The New Slave Trade," 3-4, 202. 